\title{
A Ideia de Progresso no Pensamento Sadeano: Apontamentos Sobre a Filosofia Na Alcova
}

\author{
Poliana dos Santos ${ }^{l}$
}

\begin{abstract}
RESUMO: Este artigo pretende, por meio da análise literária e da leitura de Freud (2011), investigar a concepção de progresso em Sade, tomando como objeto de estudo o romance A filosofia na alcova (2008b). Defende-se que a ficção sadeana resulta de um conflito entre indivíduo e sociedade, de cujo resultado depende a felicidade humana. Esta seria alcançada com a superação dos obstáculos impostos pela educaçấo, pela cultura e pela abertura da sociedade para a satisfação de todos os prazeres do sentido.
\end{abstract}

PALAVRAS-CHAVE: Progresso. Sade. Prazer. Ficção. Felicidade.

No século XVIII, a ideia de progresso estava associada à luta contra a ignorância e a superstição religiosa, e à busca pelo conhecimento, com base na racionalidade e no desenvolvimento do espírito humano. $\mathrm{O}$ termo progresso também estava vinculado a outros conceitos, como igualdade, liberdade, justiça, virtude e fraternidade. Assim, para o indivíduo alcançar a felicidade, era preciso superar as trevas da estupidez, comumente chamada Deus, deixandose governar pela razáo e pela ciência. Nesse momento, destacava-se uma nova representação de futuro, que deixava de ser prognosticado, como ocorria na Idade Média, e passava a ser visto como um elemento desconhecido, dinâmico e acelerado. Koselleck (2006, p. 35-36) afirma que essa imagem do tempo só foi possível com o advento de uma filosofia da história, a qual inaugurou a nossa modernidade, pondo fim a um plano temporal profético para vivenciar o contínuo e o planejado.

Essa concepção de progresso marcou toda uma geração de iluministas, tais como Voltaire, Rousseau e Condorcet. Este, em especial, erigiu um hino ao desenvolvimento do homem, com a sua obra Esquisse d'un tableau historique des progrès de l'esprit humain (1966). Nesse pequeno livro, o filósofo esboça um quadro histórico, no qual observamos dez etapas da evolução do espírito

\footnotetext{
${ }^{1}$ Doutoranda em História Social pela Universidade de São Paulo (USP) e Mestre em Estudos Literários pela Universidade Federal de Alagoas (UFAL).E-mail: poliana.stos@hotmail.com
} 
humano, registradas a partir do "estado selvagem" até os últimos avanços no campo da mecânica, da álgebra, da geometria, da química e das leis físicas do universo. Além disso, são examinados os ganhos sociais com a revolução americana e francesa, assim como os princípios sob os quais esses movimentos se constituíram, isto é, no fundamento crítico aos padres e à tirania política. O derradeiro passo da humanidade em direção à prosperidade estaria circunscrito à esperança de uma sociedade igualitária. Nesse sentido, a décima etapa seria aquela em que se testemunharia utopicamente o fim da desigualdade entre as naçóes, o alargamento da igualdade num mesmo povo e o aprimoramento real do homem (CONDORCET, 1966, p. 253).

O progresso, consoante Condorcet, era o resultado do desenvolvimento das faculdades humanas, e independia da vontade daqueles que o desejavam deter. Ele seria, portanto, uma marcha natural do indivíduo coletivo, podendo manifestar-se de forma lenta ou rápida, mas nunca de modo retrógrado. Os motivos, que levariam certos grupos a permanecer num estado cultural ou a caminhar a passos lentos, são vários: o clima, os hábitos, a ignorância e a resistência à novidade, a preguiça do corpo e do espírito, a superstição, entre outros (CONDORCET, 1966, p. 97). Já o contato e a troca entre os povos seriam os elementos que induziriam a um avanço mais acelerado. E a escrita teria sido basilar para isso, já que ela foi um meio de assegurar as tradiçóes e transmitir o conhecimento.

Nesse contexto, o progresso seria, antes de tudo, o desenvolvimento intelectual e científico do homem em prol da sociedade. "Nous voyons que les travaux de ces derniers ages ont beaucoup fait pour le progrès de l'esprit humain, mais peu pour le perfectionnement de l'espèce humaine; beaucoup pour le gloire de l'homme, quelque chose pour sa liberté, presque rien encore pour son bonheur" (CONDORCET, 1966, p. 249). A melhoria das faculdades do espírito deveria estar associada à virtude e ao respeito pelos direitos naturais e pela felicidade comum. Condorcet projetou um mundo perfeito, em que os indivíduos não fossem divididos entre aqueles que comandam e aqueles que obedecem; ele pensou numa história que não fosse narrativa de alguns homens ou chefes, mas da humanidade inteira, da massa das famílias, daqueles que trabalham e agem para o bem geral. Em suma, podemos sustentar, como afirmam Moni-

\footnotetext{
2 "Nós temos visto que os trabalhos destes últimos anos foram muito para o progresso do espírito humano, mas pouco para o aperfeiçoamento da espécie humana; muito para a glória do homem; alguma coisa para sua liberdade, quase nada ainda para sua felicidade" (tradução nossa).
} 
que e François Hincker (1966, p. 62), que a obra desse pensador é, em primeiro lugar, o testamento filosófico do século XVIII.

Entretanto, um conceito bem particular sobre o aperfeiçoamento humano foi elaborado, também nesse século, por Donatien Alphonse François (1740-1814), o marquês de Sade. Ele procurou ampliar os direitos do homem para outro campo, além do político e do social, debruçando suas reflexôes para uma filosofia que exaltasse o prazer e o sexo. Este era percebido sem a instância moral de certo ou errado, e sem a distinção de gêneros. Desse modo, é pelo olhar da sexualidade que esse escritor buscou contribuir para o progresso coletivo, colocando-se na contracorrente do pensamento filosófico tradicional e erigindo o corpo como principal núcleo avaliador dos valores e das ideias (GIANNATTASIO, 2012).

Porém, quem era esse homem? E sob quais circunstâncias ele desenvolveu seu pensamento? Filho da aristocracia, que tinha parentesco com a linhagem real, Sade foi um garoto mimado e autoritário. Além de prestígio na vida pública, sua família possuía consideráveis bens, como um castelo e terras em La Coste, possessóes em Saumone, Mazan e Paris. Uma parte de sua infância passou no Palácio Condé, junto com o príncipe Louis-Joseph de Bourbon, mas, em consequência das brigas com a pequena majestade, foi levado para viver com a sua avó em Avignon, durante dois anos. Mais tarde, foi morar com o tio, o abade Jacque-François, conhecido por seus atos libidinosos. Aos dez anos de idade, o garoto retornou para Paris, a fim de estudar no Collège Louis-le-Grande, uma escola destinada à nobreza, onde passou quatro anos. Com 15 anos de idade, ele já havia sido nomeado como subalterno na infantaria de Guarda Real de Luís XV, chegando a participar da "Guerra dos Sete Anos", entre a França e a Inglaterra, em 1756. Foi durante esse conflito que começou os rumores sobre os seus desejos inflamáveis em relação às mulheres (THOMAS, 1992).

Com efeito, para frear as atitudes sexuais do jovem marquês e angariar maiores recursos financeiros, seu pai decidiu casá-lo com Renée-Pélagie, filha de uma família materialmente promissora, mas sem ligaçôes com a nobreza. Contudo, em 1763, após seis meses de vida conjugal, Donatien Alphonse François foi levado à prisão de Vincennes, acusado de atos de libertinagem. Em 1768, é novamente preso, em Lyon, por açoitar uma pedinte e aplicar cera quente nos seus ferimentos - o caso Rose Keller. Em 1772, é sentenciado à morte por prática de sodomia e tentativa de envenenamento, numa festa orgiástica. Esse episódio o levou a uma série de prisóes e fugas, que totalizaria um cárcere de vinte e sete anos. Deve-se frisar que tâo longo encarceramento 
foi também incitado pela senhora de Montreuil, sua sogra. Ela não mediu esforços para pôr e manter o genro na cadeia, vingando-se da vergonha que ele fizera à família (THOMAS, 1992).

Com a Revolução Francesa, Sade foi solto em função da anistia concedida a todos os presos do regime anterior, condenados sob a lettres de cachet, isto é, uma carta escrita por ordem real com objetivo específico de punir certos indivíduos. A fim de assegurar a sua liberdade e a sua vida, já que era um nobre, ele se tornou um membro ativo da revolução, participando como secretário da Section des Piques ${ }^{3}$ e da Guarda Nacional. Além disso, chegou a ser juiz e presidente de um tribunal revolucionário, embora curiosamente fosse contra a pena capital (THOMAS, 1992, p. 165-170).

Em 1793, seria novamente preso, acusado de atividades contrarrevolucionárias, porque havia livrado algumas famílias da guilhotina, inclusive os Montreuil. Logo após a morte de Robespierre, a fase de terror começava a se arrefecer e Sade se viu outra vez livre. No entanto, ele estava arruinado, com sua riqueza nas mãos do Estado, passando fome e frio, morando no fundo de um celeiro em Versalhes com a sua nova paixão, a jovem atriz Marie-Constance e o pequeno filho dela. Em 1801, seria encarcerado e transferido para o manicômio de Charenton, onde morreria aos 74 anos, sob o regime de Napoleão Bonaparte. $\mathrm{O}$ marquês já estava parcialmente cego, sofrendo de gota e de reumatismo. Segundo Thomas (1992, p. 194), os motivos dessa detenção não são muito claros, todavia, as evidências levam a crer que a causa seria a obra Juliette e, talvez, o panfleto Zoloé e os Dois Acólitos, que caçoavam de Napoleão e Josefina. Em suma, Sade vivera entre o esplendor da riqueza e da extrema miséria. Entretanto, nos momentos finais de sua vida, seus bens materiais foram restituídos, promovendo certo conforto, como direito a visitas, a livros e a amantes.

Foi durante o encarceramento que o marquês se tornou um autor de romances e contos eróticos, revelando à sociedade uma imaginaçáo sexualmente terrificante e criminosa. Entre as suas principais obras, estão 120 dias de Sodoma (2011), Os infortúnios da virtude (2008a) e A Filosofia na alcova $(2008 \mathrm{~b})^{4}$. O escritor fora visto, por muitos, como um homem de uma mentalidade monstruosa e perversa; e, por outros, como a expressão heroica da individualidade contra a repressão. Ainda consoante Thomas (1992, p. 195),

\footnotetext{
${ }^{3}$ Durante a Revolução Francesa, Paris foi dividida em "seçôes" que deviam constituir a base do governo da cidade, uma das quais foi a Section des Piques (THOMAS, 1992, 165).

${ }^{4}$ Com exceção do livro Os 120 dias de Sodoma, que permaneceu por muito tempo perdido numa cela da Bastilha, os outros romances foram respectivamente publicados em 1787 e 1795.
} 
"[...] a verdadeira liberdade, para Sade, se radicava sempre no interior de sua mente, e era a usurpação desse direito que mais violentamente o atingia”.

Camus (2005, p. 53) tinha igualmente uma visão bastante interessante sobre o marquês. Ele explica que tantos anos de confinamento não poderiam produzir uma inteligência conciliadora. A intensa reivindicação pela liberdade e pela vida teria levado Sade ao extremo da negação, transformando seu desejo de existir em um sonho de destruição universal. Assim, sua revolta é também a mais absorvente. Sua insurreição é a do não absoluto. Nesse sentido, as sociedades idealizadas por Donatien Alphonse François são moradas apenas das paixóes e dos instintos. Sua utopia se constrói sobre todos os atos ligados ao prazer, até mesmo o assassinato. Em certo ponto, temos uma divergência com Camus, porque, ao exaltar o gozo e o deleite como clímax do seu sistema social, Sade se realiza ainda num sim absoluto. Esse sim pode ser testemunhado tanto em sua produção ficcional quanto no campo do real. E a sua resistência à prisão, sua batalha pela liberdade, sua luta para manter-se vivo e lúcido na cadeia confirmam isso. Esse sim à vida, que tanto nos lembra Nietzsche ${ }^{5}$, pode ainda ser ratificado quando o escritor livrou a implacável família de sua esposa, os Montreuil, da famigerada guilhotina, durante o cargo que ocupou como juiz da corte revolucionária.

Enfim, o marquês fora uma figura ambígua. E o sentimento que ele despertou, ao longo de séculos, oscila na mesma extremidade em que foi a sua vida. Ele foi amado e odiado, visto como um injustiçado e um homem monstruoso; tomado ora como louco, ora como lúcido; qualificado como demoníaco e divino. Todavia, nenhuma dessas definições é tão emblemática como a imagem do filósofo acorrentado, vítima do preconceito de seu tempo. A esse

\footnotetext{
${ }^{5}$ Borges (2008, p. 237) enfatiza que entendemos melhor o pensamento sadeano por meio da crítica empreendida por Nietzsche aos valores morais, um século mais tarde. Tanto Sade quanto o pensador alemão concebem a vida como ela é, naquilo que ela tem de mais alegre e doloroso. Defendendo a plena existência do indivíduo e o reconhecimento de pessoas fortes e fracas, eles condenam o cristianismo e a polaridade dos valores, tal como o bem/o mal, cujos conceitos foram negativamente invertidos. Para Nietzsche, a vida é apresentada como apropriação, violação, dominação e força. Assim, o existir seria uma vontade de potência, uma luta sem trégua, expressa na manifestação da força e sua resistência (cf. MARTON, 1993, p. 64). Entretanto, devemos ressaltar que a ideia nietzscheana da existência como combate não se confunde com o extermínio ou o aniquilamento do adversário (ibidem, p. 60), como observamos em Sade. Em Os 120 dias de Sodoma (2011, p. 265), o devasso Curval explana, para seus amigos libertinos, a nulidade humana: "[...] e que diabo pode valer para a natureza um, dez, vinte, quinhentos homens a mais ou a menos no mundo? Será que os conquistadores, os heróis, os tiranos, se impóem essa lei absurda de não ousar fazer aos outros o que nâo queremos que nos seja feito?" Além disso, as personagens-vítimas do escritor não oferecem nenhum tipo de resistência, aceitando seu estado de submissão. Somente a dominação do libertino se efetiva, não havendo força contrária.
} 
quadro é associado à pintura de um homem que, por meio da linguagem, procurou destruir toda crendice cristã e o ideário de progresso iluminista, revelando o desligamento entre a virtude e a liberdade. Desse modo, não haveria uma aliança secreta e natural entre a moralidade e o destino dos homens. A moral separada da fonte religiosa não resistiria.

\section{$* * *$}

Embora Sade seja um leitor dos pensadores iluministas e faça referência a autores como Montesquieu, La Mettrie, Fontonelle, Rousseau e Voltaire, ele não compactuou com o progresso das Luzes. Ao contrário, vemos nos escritos sadeanos um desvirtuamento ou uma radicalização dos discursos e dos sentidos filosóficos, geralmente, modificados pela omissão de algum assunto ou pela substituição de uma palavra (BRIX, 2007, p. 17). Devemos enfatizar que tais discursos são ressignificados para legitimar e justificar as açóes criminosas das personagens sadeanas, que respondem apenas ao gozo e às pulsóes animais do indivíduo.

Nesse sentido, o livro A filosofia na alcova $(2008 \mathrm{~b})^{6}$ é bastante expressivo, a começar por sua estrutura interna dividida em sete diálogos, à maneira do teatro. Os seres fictícios do romance, entre práticas e encenaçóes eróticas, conversam, numa contestação fremente, sobre o homem e sua natureza, costumes e convençôes sociais, diversidade e relativismo cultural. Daí resulta o título sugestivo da obra. A narrativa se constrói através de uma des(educação) dos costumes e dos valores cristãos, por parte da jovem Eugenie, que é introduzida no universo da libertinagem pelas personagens devassas Saint-Ange e Dolmancé. Durante o processo de aprendizagem, a adolescente é instruída a se libertar de todos os preconceitos culturais e a realizar toda sorte de crimes em nome do prazer. Segundo Borges (2008, p. 215), o que se vê é uma educação pelo avesso, em que é atacado "[...] tudo aquilo que de alguma forma se interpóe entre o indivíduo e a sua felicidade".

Notamos frequentemente nos diálogos e nas doutrinas libertinas uma crítica sarcástica aos filósofos iluministas. Assim, enquanto Rousseau, em $A$ origem da desigualdade entre os homens ([2005?], p. 50), discorre sobre a piedade como um sentimento natural, afirmando que o homem é em si mesmo bom, sendo corrompido em sociedade, Sade (FA, p. 44), por meio de Dol-

\footnotetext{
${ }^{6}$ Em razão dos vários fragmentos textuais que utilizamos d'A filosofia na alcova, as citaçôes dessa obra serăo feitas através de suas siglas iniciais (FA) e do número de página.
} 
mancé, ironiza esse discurso, assegurando que a caridade é uma convenção social, o maior de todos os embustes, não promovendo a felicidade de nenhum espírito sensível. Ao passo que o mesmo Rousseau eleva o aforismo "[...] não faça aos outros, aquilo que você não quer que lhe façam” como a máxima da bondade natural (ROUSSEAU, [2005?], p. 51), o marquês vê nesse dito uma recomendaçáo absurda, vinda dos primeiros cristãos que, nas palavras sadeanas, seriam seres fracos, obrigados a mendigar a piedade em face das perseguiçóes e angústias sofridas. Para o autor, Deus e o cristianismo são um falso princípio, a fonte de todos os erros morais, que se manteve à custa de atrocidades como a fogueira $(F A$, p. 80,111$)$.

Para compreender, enfim, a concepção que Donatien Alphonse François tem de progresso, é necessário, antes de tudo, entender o seu conceito de natureza, o qual foi emprestado de pensadores tais como o médico La Mettrie e o naturalista Buffon. Para o marquês, a natureza é a matéria em movimento, é a ação criadora e mantenedora, que se manifesta por combinaçôes desconhecidas (FA, p. 39). Ela é, assim, indiferente à virtude e à moral, não fazendo distinção de bem ou de mal. Sua lei obedece apenas ao prazer e às paixóes; e a crueldade é o primeiro sentimento que ela nos transmite. Em mais uma alusão mordaz a Rousseau, o autor defende que a barbaridade está mais próxima do homem selvagem do que do ser civilizado, e que a crueldade seria a energia do indivíduo que a civilização ainda não corrompeu:

[...] Todos nascemos com uma dose de crueldade que só a educaçáo modifica; mas a educação não está na natureza e prejudica tanto seus efeitos sagrados quanto o cultivo prejudica as árvores. [...] A crueldade não é outra coisa senáo a energia do homem ainda não corrompida pela civilização; é uma virtude, portanto, e náo um vício. [...] É no estado de civilização que ela se torna perigosa, porque quase sempre falta ao ser lesado força ou meios de repelir a injuria; mas num estado incivilizado, se ela age sobre o forte, será repelida por ele, e se age sobre os fracos, não lesando senão um ser que cede ao mais forte pelas leis da natureza, não terá a menor inconveniência. ( $F A$, p. 81$)$.

Nesse contexto, todos os atos libertinos são inspirados pela voz da natureza, não havendo vontade ou crime, o mais bizarro, que não faça parte de seu desígnio. Desse modo, a pedofilia, a sodomia, a coprofilia, a zoofilia, o incesto, o estupro, o roubo, o adultério, a prostituição e o assassinato, quando guiados pelas paixóes e por nossas expansóes naturais, são inteiramente legítimos. A concepção de um estado natural da violência não é, contudo, uma novidade trazida pelo marquês. No século XVIII, existia mais de um filósofo que defendia, a 
exemplo de La Mettrie, a ideia de que na natureza não havia nada de justo ou injusto; para ela, isso era insignificante. Os preceitos de bom ou ruim variavam em função dos costumes e das culturas de cada povo (BRIX, 2007, p. 15-18).

Até mesmo Hobbes (2003), no século XVII, já afirmava que a felicidade é uma marcha inconstante dos desejos humanos. E que a condiçấo primitiva do indivíduo é de um estado de guerra, em que todos estáo contra todos. Nessa situação, não haveria lugar para termos como justiça ou injustiça, pois, num conflito, a força e a fraude seriam virtudes fundamentais. Conforme o filósofo, tal condição daria ao homem o direito de fazer tudo o que desejasse, até mesmo possuir os corpos uns dos outros. As categorias de bem e de mal seriam, na realidade, divergências de costumes e temperamentos, não fazendo parte da faculdade do espírito, mas de qualidades que pertenceriam a uma dada sociedade. No entanto, Hobbes (2003, p. 111-112) levanta uma barreira contra a liberdade ilimitada da natureza humana, afirmando que "[...] a razão sugere adequadas normas de paz (Lex Naturalis), em torno das quais os homens podem chegar a um acordo", preservando assim a sua vida.

Devemos sublinhar, no entanto, que, diferentemente dos outros pensadores, Sade não impóe limite à crueldade vital. A ferocidade nada mais é do que energia. Além do mais, ele não aconselha que, diante da escolha entre a beneficência e a corrupção, seja preferível a primeira, vista como aparente. Pelo contrário, o marquês ( $F A$, p. 79$)$ sugere a excitação dos nossos desejos mais dissolutos e destrutivos, a fim de ativar, por meio de vibraçóes nervosas, os espíritos animais que promoveriam o máximo deleite. É, com efeito, baseado nessas percepçóes que as personagens sadeanas são esquematizadas e se movimentam. As figuras devassas, comumente ricas, belas e inteligentes, vivem e agem de modo nefando, à caça de vítimas que alimentem seus estímulos carnais. Elas só ouvem o chamado da natureza e, por conta disso, são excepcionais. Dessa maneira, Eugenie é iniciada no mundo da perversão e da aversão moral; e sua educação visa a incitar a mente e o corpo para a sensibilidade libertina, desobstruindo sua potência natural dos condicionamentos sociais. Consoante Giannattasio (2012, p. 69), n’A filosofia da alcova as ideias estão submetidas ao crivo do corpo, o que significa "[...] empregar um mecanismo de avaliação que vai da experiência sensível, como campo privilegiado de construção de significação, ao cognoscível”.

Os seres fictícios, que estão abertos para o vício, a respeito de Dolmancé e Saint-Ange, são classificados entre aqueles personagens superiores, os quais se localizam além de qualquer fronteira. Os libertinos, que se encontram 
acima da moral e do saber local, estấo constantemente transgredindo as normas sociais e cometendo toda espécie de crime. São indivíduos, geralmente nobres, que tiveram uma educação refinada e que superaram o medo da morte e da destruição. A morte, para eles, não seriam o fim, mas tão somente a modificação da matéria. Esse argumento seria uma das justificativas para o assassinato, pois os devassos estariam, na verdade, devolvendo uma substância necessária ao movimento autônomo da natureza. Esta, por sua vez, favorece aos libertinos, protegendo-os e abrigando-os. Dessa maneira, eles escapam de todo ato punitivo e seus planos sempre são executados.

É significativo observar que as personagens que não se submetem ao universo da libertinagem são passíveis de punição. Sobre elas recai a fúria dos lúbricos, que buscam castigar todo aquele que, tomado por questóes éticas, sustenta o preconceito, a crendice e a hipocrisia social. Esse é o caso da senhora de Mistival, mãe da jovem aprendiz, que é condenada, com o consentimento da filha, a sofrer várias agressóes sexuais, tais como ser infectada por sífilis e ter suas partes íntimas costuradas. Em Os infortúnios da virtude (2008a), a protagonista Justine sofre igualmente vários castigos, em razão de sua conduta virtuosa. Ela é explorada, roubada, aprisionada, mutilada e abusada sexualmente. E, entre seus algozes, encontravam-se nobres, prostitutas e até padres. Entretanto, a heroína não perde a sua fé na justiça e na bondade divina. Para cada ato de generosidade e probidade, ela padecia o mais violento infortúnio. Era como se o acaso mostrasse que o caminho para a prosperidade era alcançado pela ação corruptível. A teimosia de Justine em não aceitar os ditames de uma natureza cruel a conduz para uma penalizaçáo maior, ou seja, a morte, causada por um raio que atravessa o seu corpo. A atrocidade, agora, não advém dos seus carrascos, mas da própria natureza que manifesta seu repúdio, vingando-se da beneficência, simbolizada na protagonista.

Em suma, as personagens sadeanas são, na maioria das vezes, organizadas em dois sentidos, ou seja, aquelas que acatam o seu impulso natural e aquelas que rejeitam esse impulso. No entanto, algumas figuras são fronteiriças, porque estariam situadas entre um comportamento devasso e manifestações de caridade. Essa função é desempenhada no romance pelo Cavaleiro, o qual tenta refutar os princípios de Dolmancé, orientando Eugenie para uma conduta mais branda, na qual esteja liquefeito o deboche, a concupiscência e o altruísmo.

Borges (2008, p. 10-12) comenta, com propriedade, que as obras do marquês são construídas de forma polifônica, entrecruzando parodicamente 
o idealismo sentimental e a visão libertina. Assim, os seus textos procurariam ridicularizar e destruir toda sensibilidade romântica do século XVIII, configurada na ideia de amor ao próximo, de solidariedade e de arrependimento.

É curioso que o nome da principiante não denota somente a imagem de uma moça rica, mas também de uma garota pura - Eugenie significa aquela que é "nobre", de "boa casta" (SADE, 2008a, p. 214). No livro, observamos uma guerra declarada entre a virtude e o vício, na qual a primeira, em regra, sai perdendo. $\mathrm{E}$ isso acontece porque a sociedade se move em contraposição a natureza, não obedecendo a seus códigos. A compaixão e a generosidade seriam valores que comprimem a vitalidade humana, agindo como forças repressoras. Partindo dessa lógica, a humanidade jamais alcançaria a felicidade, já que estaria sendo educada para ser algo que ela não é. O ser humano nunca chegaria ao aprimoramento, enquanto os seus desejos estiverem sendo repreendidos pela falsidade ou aparência social.

É significativo explicar que $A$ filosofia da alcova foi escrita durante a fase mais aterrorizante da Revolução Francesa, quando Sade estava na prisão de Picpus. Ele testemunhou a carnificina e a mortandade que Robespierre engendrou, em nome da castidade e da pureza. $\mathrm{O}$ autor, portanto, procura atacar os modelos idealistas na sua obra, expondo o engodo que está por trás desses paradigmas. No Quinto diálogo do romance, é inserida uma paródia política, intitulada Franceses, mais um esforço se quereis ser republicanos, em que se faz referência aos assassinatos cometidos na revolução por causa da virtude. $\mathrm{O}$ artigo é apresentado como uma contribuição para o progresso das luzes, e vai pondo abaixo todos os padróes sentimentalistas e virtuosos do século XVIII.

Nesse texto, vemos a síntese das teorias e das práticas libertinas explicitadas por Dolmancé, durante o aprendizado de Eugenie. A educação religiosa e o cristianismo são os primeiros a ser atacados. Eles deviam ser destruídos, pois alimentariam a superstição, tiranizando os homens e os tornando fracos. A República, com seu sistema de igualdade e liberdade, seria incompatível com uma "religião de escravos" ( $F A$, p. 125-126). Em face disso, um novo culto deveria ser erigido, tomando como modelo o paganismo romano. Os deuses, os heróis e os ritos da Roma antiga seriam o baluarte do regime, uma vez que eram revestidos de energia, de coragem e de alegria. Diferentemente do Deus cristão, a divindade pagã estaria de acordo com as normas naturais. Em Sade, a crítica aos crimes cometidos pela religiáo é bastante contundente: “[...] vosso teísmo fez cometer muitos crimes, mas jamais conseguiu evitar um”. Essa acusação mais direta é também encorajada pela descristianização 
que aconteceu no período revolucionário, no qual se erigiu o culto da razão. Nesse sentido, Robespierre é citado como um infame que buscou novamente arrancar Deus do esquecimento (FA, p. 131-132).

O escritor investe igualmente, no seu panfleto, contra o matrimônio, empregando como argumento o fato de que todos os homens nascem livres. Um sexo, então, jamais poderia ter exclusividade sobre o outro. Assim, ele destrói a um só tempo o estabelecimento familiar e a idealização do amor. Levantando-se contra esses valores, é sarcasticamente exaltado tudo o que o cristianismo e o sentimentalismo romântico condenaram, como a prostituição, o adultério, o incesto, o estupro e a sodomia.

Entretanto, quando o marquês tece apreciaçóes sobre a nova Repúbli$\mathrm{ca}$, suas ironias se mostram astutamente mais sutis. $\mathrm{O}$ truculento e insurgente regime é tratado como uma instituição virtuosa e o povo francês como bastante sensato e esclarecido. As ideias de igualdade, liberdade e propriedade são constantemente troçadas, deixando entrever os custos e as imolaçôes humanas que elas promoveram. Assim, são feitas graves censuras contra os assassinatos perpetrados pelo governo: "[...] a segunda razão pela qual se deve aniquilar a pena de morte é que ela jamais reprimiu um crime, já que ele é cometido todos os dias aos pés do cadafalso" (FA, p. 141). A natureza selvagem e egoísta do homem, descrita nos livros sadeanos, não estava muito longe das práticas republicanas. Nesse contexto, Sade é cáustico, pois, diante de tamanha violência empreendida pela "justiça do povo", o esforço francês para alcançar o seu ideal político seria assegurar a institucionalização do crime através da legalização da calúnia, do roubo e do homicídio. A falácia da revolução é desmascarada, porque a felicidade prometida é perseguida através de formas perversas. $\mathrm{O}$ assassinato seria a mola da política: "Será ele um crime em política? Ousemos confessar, pelo contrário, ser ele, infelizmente, uma das grandes molas da política. Não foi à custa de assassinatos que Roma se tornou senhora do mundo? Não foi à custa de assassinatos que a França hoje é livre?” (FA, p. 163).

Desse modo, a incredulidade defendida e divulgada pela razão é igualmente alvo de sarcasmo: "[...] o ateísmo é no presente o único sistema dos que sabem raciocinar" ( $F A$, p. 129). Na verdade, o que se quer dizer é: a razão se manifestou tão monstruosa e irracional quanto o Deus que ela pretendeu aniquilar. $\mathrm{O}$ materialismo filosófico, que póe o homem como um ser guiado antes pela paixão e pelo desejo, é pensado no seu extremo. E o que são as figuras sadeanas, senão a expressão máxima desse ateísmo? Sem Deus, e movidos pela vontade natural, são as suas individuações que imperam. $\mathrm{O}$ reino postulado 
pela natureza é horripilante tal qual a divindade cristá. Por isso, o republicanismo é posto como o regime mais próximo dos estados naturais ${ }^{7}$.

\begin{abstract}
Agora que a respeito de tudo isso estamos curados da multidáo dos erros religiosos que nos cativavam, e que, mais próximos da natureza pela quantidade de preconceito que acabamos de aniquilar, só escutamos sua voz, estamos seguros de que, se houvesse crime em alguma coisa, seria antes por resistir às inclinaçóes que a natureza nos inspira do que por combatêlos, pois, persuadidos de que a luxúria é uma dessas inclinaçôes, trata-se muito menos de extinguir em nós esta paixão do que regrar os meios para satisfazê-la em paz. (FA, p. 146).
\end{abstract}

O universo sadeano é inventado sob o olhar invertido das teorias filosóficas e dos hábitos ocidentais, especialmente da França. Destarte, percebemos nas personagens libertinas uma lógica do absurdo, na qual é mostrada a outra face dos princípios de probidade e das convençôes culturais. Donatien Alphonse François procurou ver o indivíduo desprendido de sua educação e dos acessórios sociais que o distorcem. Por intermédio de sua obra e de sua vida, ele buscou a construção integral do homem, independentemente de certo ou errado. É por isso que sua linguagem é propositalmente violenta e desconcertante, provocando o espanto ao leitor. Sua ficção entra em choque com a tradição cristã e com as regras sociais. Seu fazer literário zomba, através do uso da ironia e do sarcasmo, dos costumes que mutilam o indivíduo. Portanto, seu imaginário não mede limites para destruir velhos códigos morais, blasfemando, debochando e rindo de todos aqueles que impóem rédeas para o exercício pleno da liberdade.

Assim, sua luta se fazia contra o despotismo e a tirania. É daí que se originaria a força da sua criação e da sua palavra. Porém, seu poder de invenção também encontraria fonte no mais obscuro de sua mente, lugar onde não haveria fronteira para o crime e para o aniquilamento absoluto da humanidade. Como explica Camus (2005, p. 59), “[...] desejar sem limites é o mesmo que aceitar ser desejado sem limites. A licença para destruir pressupóe que se possa também ser destruído. Logo, será preciso lutar e dominar. A lei deste mundo nada mais é do que a lei da força; sua força motriz, a vontade de poder".

Como apontado por Borges (2008, p. 218), a sociedade sonhada por Sade só se realizaria no plano da literatura, que, de maneira particular, inverte

7 A discussão sobre essas questões pode ser vista em Klossowski (1985), especificamente num estudo chamado "Esboço do Sistema de Sade". 
os valores morais para dizer que este mundo está fundado em princípios que não garantem a nossa felicidade, sendo necessário construirmos novas bases. A crueldade das personagens sadeanas seria, de certo modo, uma estratégia ficcional de negaçáo do real. Vimos que o livro A filosofia na alcova é, em parte, uma expressão sarcástica do regime republicano, porém, uma problemática percorre a maioria das obras sadeanas, a saber, o limite entre a ironia ficcional e as obsessóes sexuais que afloram da mente do autor. Em outras palavras, quem seria Sade? Em qual lugar de sua ficção ele está escondido?

Para Thomas (1992, p. 155), coexistiam no autor de A filosofia na alcova duas personalidades opostas, as quais se manifestavam alternadamente. Uma agia de maneira arrependida, enxergava a mulher de modo romântico e platônico, e pregava a virtude como um paradigma a ser seguido. Esse caráter estaria expresso em romances como Os infortúnios da virtude. A outra representava o seu lado mais sombrio e atroz, suas obsessōes sexuais, seus desejos de destruição, sua negação extrema da vida. Seria o seu outro eu demoníaco, identificado na obra Os 120 dias de Sodoma. Todavia, definir quem seria Sade a partir de sua produção literária é algo complexo, porque essa escritura é mediada pelos artifícios imaginários. Embora haja em seus textos indícios biográficos, não se pode tirar daí uma síntese psicológica do escritor, subestimando a dose de invenção que caracteriza o gênero ficcional.

Conforme Giannattasio (2012, p. 83-84), a literatura é a condição mais apropriada para apresentar o pensamento sadeano, porque esconde a figura autoral, o que era a intenção do marquês. Ele não conferiu uma identificação entre si e os esquemas psicológicos de seus personagens, sejam virtuosos ou não. Logo, seu estilo multifacetado e irônico permitiria expressar as suas ideias filosóficas com maior riqueza, conservando a complexidade de seu modo de pensar, sem conferir uma identidade determinada. Essa estratégia ficcional faria de Sade uma figura de difícil explicação, desafiando certas leituras psicologizantes. Em razáo disso, Bataille (2002, p. 83) afirma que o marquês está sempre escapando de nós, e que nada seria mais vão do que tomá-lo ao pé da letra. Por fim, não devemos concluir que a escrita sadeana esteja sujeita a qualquer tipo de exame pelo fato de ela se mostrar aberta e náo autoral, porque tanto o texto quanto o contexto impóem limites para a livre interpretação do crítico (BATAILLE, 2002, p. 85).

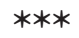


Como entender o progresso em Sade, quando o seu pensamento se constrói sobre o trágico e o destrutivo? Thomas (1992, p. 273) considera como uma qualidade inegável o fato de ele pôr "[...] o otimismo fácil dos filósofos e dos progressistas no seu ponto decisivo. O poder autodestrutivo da raça humana é o poder supremo, na opinião de Sade, e a extinção da espécie é inevitável e não deve ser lamentada. A história não é progresso, mas uma acumulação inútil”. Camus (2005, p. 56) também se refere ao escritor como inimigo da raça humana; a sua república não teria a liberdade como lema, mas a libertinagem e o extremo das paixóes, que, em geral, se converte em ódio. É interessante que esses críticos literários, embora reconheçam a ambiguidade do marquês, ainda o veem de maneira muito categórica, reforçando o seu aspecto destrutível. Acreditamos que isso acontece porque a violência representada no romance é enxergada a priori como reflexo da mente perturbada do autor. A linha que separa Sade e sua obra é tão tênue que chegamos a esquecer que a literatura é engano (PERRONE-MOISÉS, 1990, p. 101) e sua função não é somente criar admiráveis mundos novos, mas igualmente gerar desconforto, tirando-nos do eixo e da ordem a que estamos acostumados. Nisso, a criação sadeana é categoricamente grotesca.

Vale observar que esse grotesco tem uma função expressiva, pois tenciona uma atitude revolucionária. Por meio de uma ferocidade absurda e do incomum, pretende-se produzir, no campo estético, a blasfêmia. Esta se tornaria uma arma mais poderosa que o assassinato e a guerra, pois aniquilaria, por meio do ridículo e da subversão, as normas culturais e cristấs. Assim, a personagem Dolmancé disserta sobre a arte da ironia como ferramenta para derrubar a religião, tomando como argumento de autoridade a figura de Voltaire:

Não duvidemos: este culto indigno teria sido irremediavelmente destruído se desde o seu nascimento tivessem empregado contra ele tão-somente as armas do desprezo que merecia. Mas acabaram perseguindo-o, ele cresceu [...]. E se ainda hoje se tentasse cobri-lo de ridículo, cairia. O hábil Voltaire jamais empregou outras armas. De todos os escritores, é o que pode se gabar de ter feito mais prosélitos. (SADE, 2011, p. 42).

A personagem libertina explora toda forma de escárnio, seja por meio da linguagem, seja em torno das representaçóes sociais, tais como a família, o casamento e a monogamia. Estes são arruinados em favor do incesto e do adultério. Dessa maneira, Dolmancé ensina Eugenie a odiar a sua mãe, a entregar-se ao seu pai, a ter relaçóes lesbianas, a enganar seu futuro marido e a 
não procriar. $\mathrm{O}$ imaginário sadeano é anárquico, não havendo espaço para a ordem institucional vigente. Sua ficção profana todos os templos que a razáo ocidental exaltou como incorruptíveis.

Posto isso, a ideia que Donatien Alphonse François tem de progresso nos causa estranhamento, pois se opóe a tudo o que a nossa educação postulou como certo e justo. Todavia, devemos questionar o que existe por trás do prazer e da crueldade sadeana; precisamos atinar que, na sua violência ficcional, está submersa a crítica a uma sociedade que não nos satisfaz enquanto seres humanos e esfacela a nossa integridade física e intelectual. Em resposta ao mundo real, o marquês criou um mundo imaginário, regado ao gozo individual e à excitação sexual, uma sociedade utópica, na qual não existem limites para os instintos do homem. Nesse universo fictício, a natureza se torna a grande personagem. É ela quem guia os heróis libertinos, estando presente em tudo, pairando sobre todo o romance, movimentando as açóes e os desejos secretos das figuras devassas. A natureza simplesmente é; e não constituindo em predicados, tudo engloba e permite: o amor e o ódio, a vida e a morte.

Em face disso, é complexo, como explica Moraes (1994, p. 202), reconhecer a ideia de felicidade em Sade, porque sua figura estará sempre associada às imagens mais cruéis e repugnantes. Portanto, faz-se necessário ultrapassar esse estereótipo da crueldade, vendo o suplício sadeano como "[...] manifestação superior de uma energia que, inscrita em todos os homens, foi forçada a calar-se ou manter-se nos cantos obscuros de uma consciência conciliada a lei" (MORAES, 1994, p. 137).

Nesse sentido, o ideal de progresso ou da busca pela felicidade não estaria, para o autor em estudo, na virtude ou nas leis sociais, mas na realização dos prazeres e dos impulsos. É somente através da libertinagem e da satisfação voraz que estaríamos em acordo com a totalidade humana, com o mais íntimo de nosso ser. Enquanto a sociedade ignorar a nossa condição natural, ou seja, a de seres movidos pela paixão e pela dor, jamais se alcançará a prosperidade, porque seremos constantemente podados por regras que mutilam a nossa energia interior. Aliás, a prosperidade humana não se realizaria apenas no império dos sentidos, mas no reconhecimento de que os homens não são iguais, já que pensam, desejam e agem diferentes. O desconhecimento da distinção entre indivíduos seria um dos maiores obstáculos ao avanço social.

No livro Os 120 dias de Sodoma (2011), num diálogo entre as personagens debochadas, discute-se radicalmente o melhor modo de ser feliz. A 
essência da felicidade não estaria apenas na concretização de todos os prazeres do sentido, mas no rompimento dos freios que os impedem. Diante da conclusão filosófica de que a natureza humana é egoísta e movida pela paixão, é no sofrimento e na comparação da miséria alheia que o sujeito se considera bem-aventurado: "[...] é a visão de quem sofre e não goza daquilo que tenho que nasce o charme de poder se dizer: portanto, sou mais feliz do que ele. Em qualquer lugar onde os homens serão iguais e onde essas diferenças faltarem, a felicidade nunca existirá" (SADE, 2011, p. 142).

A estrutura interna dos romances sadeanos é percorrida por uma tensão. No livro em análise, por exemplo, há um conflito estabelecido entre a escolha do prazer (de caráter subjetivo) ou do bem comum. Isso também pode ser observado em Os infortúnios da virtude (2008a), que, a despeito de pretender ser um modelo ético, póe constantemente em dúvida a validade desse modelo, por meio de figuras como Bressac e Dubois. A própria Justine, a personificação da beneficência, parece ser vítima do destino ou da natureza, que está o tempo todo mostrando a impossibilidade de uma sociedade filantrópica. $\mathrm{Na}$ tessitura narrativa, existe um embate entre o modo instintivo do homem e aquilo que chamamos de cultura. Para Sade (2008a), a educação, os costumes e as regras sociais se configuram em barreiras que entravam a manifestação dos impulsos vitais; todavia como liberá-los inteiramente, sem correr o risco de uma barbárie? Num diálogo entre Eugénie e Dolmancé, este expôe a dissonância entre a esfera do particular e o domínio coletivo:

Porque as leis náo são feitas para o particular, mas para o geral, o que as coloca em contradição perpétua com o interesse pessoal, já que o interesse pessoal sempre se opóe ao geral. Mas as leis, boas para a sociedade, são péssimas para os indivíduos que as compóem; pois, a cada vez que os protegem ou os garantem, elas os oprimem e os escravizam três quartos de sua vida [...] (SADE, 2008a, p. 115).

Esse dilema será analisado, mais de um século depois, por Freud, em sua célebre obra $O$ mal-estar na civilização (2011). Conforme o psicanalista, a grande finalidade da vida humana é alcançar a felicidade, mas esta somente pode ser obtida pela satisfação do prazer, cuja efetivaçáo é expressa por duas metas: a vivência de fortes desejos (aspecto positivo) e a ausência de desprazer (aspecto negativo). O primeiro alvo, apesar de ser mais tentador, pode acarretar puniçóes, já que o indivíduo póe o gozo irrestrito à frente das normas. $\mathrm{O}$ segundo, mais predominante, acontece quando evitamos o sofrer utilizan- 
do várias estratégias como o isolamento, remédios, sublimação, controle dos impulsos, entre outros. Contudo, nenhum desses procedimentos é completamente eficaz, pois as aptidóes represadas podem ser bastante resistentes e imperiosas para impor a sua vontade.

A felicidade é posta como um problema libidinal, portanto, de caráter individual. O homem é guiado pelo princípio de prazer, mas também por certo grau de agressão. E ele tem necessidade de expurgar suas energias vitais:

[...] as pessoas gostam de negar, é que o ser humano não é uma criatura branda, ávida de amor, que no máximo pode se defender, quando atacado, mas sim que ele deve incluir, entre seus dotes instintuais, também forte quinhão de agressividade. Em consequência disso, para ele o próximo não constitui apenas um possível colaborador e objeto sexual, mas também uma tentação para satisfazer a tendência à agressáo, para explorar seu trabalho sem recompensá-lo, para dele se utilizar sexualmente contra a sua vontade, para usurpar seu patrimônio, para humilhá-lo, para infligir-lhe dor, para torturá-lo e matá-lo [...] (FREUD, 2011, p. 57).

No entanto, essa potência do "eu" é restringida pelo mundo exterior. A civilização, que visa ao bem-estar comum, cria leis, tabus e sentimentos de culpa, para que os instintos mais poderosos dos seres humanos sejam represados. A sociedade elabora mecanismos de punição para corrigir o capricho individual, tal como a tendência à agressão e à sexualidade, que estaria limitada às relaçóes uniformes, monogâmicas e reprodutoras. $\mathrm{O}$ indivíduo que desviasse sexualmente desse modelo era extremamente castigado, como no caso da sodomia, no século XVIII. Com efeito, um problema emerge dessa situação, isto é, a impossibilidade da felicidade no mundo civilizado, visto que este se apresenta como um obstáculo à concretização de nossos impulsos pessoais e de nossa violência.

Freud (2011, p. 68) acredita que existem no ser humano duas tendências em constante conflito: a satisfação pessoal versus a integração em comunidade. O destino da felicidade humana dependeria da solução desse conflito. $\mathrm{Na}$ realidade, o sentido da evoluçáo cultural se apresentaria nessa luta vital entre a civilização (processo a serviço de Eros) e o instinto natural de agressão (representante maior do instinto de morte). A cultura seria obra de Eros, que visa a "[...] juntar indivíduos isolados, famílias, depois etnias, povos e nações numa grande unidade, a da humanidade"; porém, o prazer de agredir das pessoas se opóe a esse programa (FREUD, 2011, p.57). A união do grupo 
promoveria uma perda de felicidade, já que esta, sendo de aspiração egoísta, ameaçaria a segurança da coesão almejada. A prosperidade humana, por conseguinte, resultaria de um possível equilíbrio entre a satisfação individual e a comunidade. Entretanto, o psicanalista não vê uma saída plausível, nega-se ao papel de profeta, finalizando seu pensamento com a seguinte questão: em que medida o desenvolvimento da sociedade poderá controlar as perturbações trazidas pelos instintos de agressão e autodestruição? (FREUD, 2011, p. 93).

Em Sade, essa luta entre a civilização e o instinto de agressão é representada de forma trágica. Não há negociação entre as duas partes. A natureza humana se nega a sacrificar qualquer desejo em nome da integração e da tranquilidade comum. Sua obra é a mimese da complexa convivência entre indivíduo e cultura. Em face disso, seu fazer literário é violento e angustiante. Sua ficção procura, por meio do avesso, solucionar essa tensão, dando vazão aos impulsos mais sombrios do homem, deixando a liberdade humana fluir sem limites. Nesse caso, as personagens libertinas submetem o pensamento filosófico ao corpo e às paixôes, porque aí estaria localizada a chave para felicidade. A razão a serviço de valores artificiais, como aqueles voltados para a virtude e o comedimento, geraria mais contenção e tristeza. A sua filosofia revela que a plenitude do ser não seria atingida enquanto as ideias morais, de base ainda religiosa, fossem componentes constitutivos do ideário de sociedade. Tal problema seria um dos fatores que dificultaria a execução do plano iluminista de progresso.

O homem integral sadeano não reconhece o mal e nem a morte, porque tudo faria parte do desígnio da natureza e das paixóes. A felicidade estaria na satisfação dos prazeres; e tanto fazer malefícios como recebê-los promoveria a liberação do gozo. Um paradoxo é então estabelecido, ou seja, aquilo que incita a destruição é também o que me enche de vida. Há no indivíduo uma radical afirmação e uma radical negação, na qual todas as coisas são permitidas. Assim, está instalado o reino do absoluto. E, para atingi-lo, é preciso libertar a energia humana a que a civilizaçáo abdicou e enfraqueceu, devido ao falso exercício da piedade e da gratidão (GIANNATTASIO, 2012, p. 109). Esse mundo ideal é irrealizável na prática, porque seria governado pelo instinto de agressão que, em busca do prazer pessoal, levaria ao sacrifício da humanidade inteira. O seu espaço é o da representação e o da imaginação, existindo apenas enquanto linguagem. No entanto, a obra de Sade é representativa da mentalidade e da experiência do seu tempo. Uma porção da realidade é manifestada na ironia que ele constrói dos hábitos sociais e sentimentais de sua época. Ademais, o escritor tocou em questóes que ainda intrigam o pensamento fi- 
losófico e toda criatura humana, a saber: o que é o homem? E como alcançar a felicidade?

SANTOS, Poliana dos. The Idea of Progress in Sadean Thought: Notes on La Philosophie Dans le Boudoir. Trans/Form/Ação, Marília, v. 37, n. 2, p. 147-166, Maio/Ago., 2014.

\begin{abstract}
The goal of this article is to investigate the concept of progress in Sade's work through the analysis and reading of Freud's work, focusing here on the analysis of the novel Justine. It argues that Sadean fiction is the result of a conflict between each individual and society, and that the happiness of humankind depends on the outcome of this conflict. Happiness would consequently be reached by overcoming the accumulation of obstacles imposed by education and culture, and through the willingness of the society to satisfy every pleasure of the senses.
\end{abstract}

KEYWORDS: Progress. Sade. Pleasure. Fiction. Happiness.

\title{
REFERÊNCIAS
}

BATAILLE, Georges. Sade. In: La littérature et le mal. Paris: Gallimard, 2002.

BORGES, Contador. A revolução da palavra libertina. In: SADE, Marquês de. A filosofia na alcova ou os preceptores imorais. Tradução de Contador Borges. São Paulo: Iluminuras, 2008.

BRIX, Michel. Sade est-il un philosophe des Lumières? Trans/Form/Ação, v. 30, n. 2, p. 1122, 2007. Disponível em:<http://www.scielo.br/scielo.php?script=sci_arttext\&pid=S0101$1732007000200002 \&$ lang=pt >. Acesso em: 27 jan. 2012.

CAMUS, Albert. O homem revoltado. Tradução de Valeria Rumjanek. 6. ed. Rio de Janeiro: Record, 2005.

CONDORCET. Esquisse d'un tableau historique des progrès de l'esprit humain. Paris: Éditions Sociales, 1966.

FREUD, Sigmund. O mal-estar na civilização. Tradução de Paulo César de Sousa. São Paulo: Companhia das Letras, 2011.

GIANNATTASIO, Gabriel. O corpo em Sade e Nietzsche ou, quem sou eu, agora? Londrina: EDUEL, 2012.

HINCKER, Monique; HINCKER, François. Introduction. In: CONDORCET. Esquisse d'un tableau historique des progrès de l'esprit humain. Paris: Éditions Sociales, 1966.

HOBBES, Thomas. Leviatã: ou matéria, forma e poder de uma República eclesiástica e civil. Tradução de João Paulo Monteiro e Maria Beatriz Nizza da Silva. São Paulo: Martins Fontes, 2003. p. 106-137. 
KLOSSOWSKI, Pierre. Sade meu próximo; o filósofo celerado. Tradução de Armando Ribeiro. São Paulo: Brasiliense, 1985.

KOSELLECK, Reinhart. Futuro passado: contribuição à semântica dos tempos. Tradução de Wilma Patrícia Maas e Carlos Almeida Pereira. Rio de Janeiro: Contraponto, 2006.

MARTON, Scarlett. Nietzsche: a transvalorização dos valores. São Paulo: Moderna, 1993.

MORAES, Eliane Robert. Sade: a felicidade libertina. Rio de Janeiro: Imago, 1994.

PERRONE-MOISÉS, Leyla. A criação do texto literário. In: Flores da escrivaninha: ensaios. São Paulo: Companhia das Letras, 1990.

ROUSSEAU, Jean-Jacques. A origem da desigualdade entre os homens. Tradução de Ciro Mioranza. São Paulo: Escala, [2005?].

SADE, Marquês de. Os 120 dias de Sodoma: ou a escola da libertinagem. Tradução de Alain François. São Paulo: Iluminuras, 2011.

. Os infortúnios da virtude. Tradução de Celso Mauro Paciornik. São Paulo: Iluminuras, 2008a.

. A filosofia na alcova ou os preceptores imorais. Tradução de Contador Borges. São Paulo: Iluminuras, 2008b.

THOMAS, Donald. Vida e obra do marquês de Sade, o filósofo libertino. Tradução de Múcio Bezerra. Rio de Janeiro: Civilização Brasileira, 1992.

Recebido em: 02/01/14

Aceito em: 13/01/14 